\title{
Lateral neck dissection in laryngeal carcinoma cases
}

\author{
Латерална шийна дисекция при ларингеален каризином
}

\author{
Julian Hadzhiev, MD, PhD \\ Department and clinics of ENT diseases, Medical faculty, Medical university - Sofia, \\ University hospital "Tsaritsa Joanna“ \\ д-р Юлиян Хаджиев, д.м. \\ Катедра и клиника по УНГ болести, Факултет „Медицина“, Медицински университет - София, \\ УМБАЛ „Царица Йоанна - ИСУЛ“ЕАД
}

L aryngeal carcinoma is the most frequent malignant tumor in the head and neck area. One of the most important prognostic factors for it are the regional metastases $(\mathbf{2 9}, \mathbf{3 0}, \mathbf{7})$. Cervical metastases in laryngeal carcinoma cases remain the first reason for failure in the treatment and lead to death of the patient (9). So treating neck area is one of the main aims of every head and neck oncologist. The main methodology for curing the neck metastases remains the neck dissection. Neck surgery aids at removing all enlarged lymph nodes at $\mathrm{N}+$ and gives accurate histologic information if micrometastases are diagnosed at N0. While in cases with clinically manifested metastases surgeon's behavior is clear, in cases with N0 the therapeutic method is unclear (10-14).

The larynx is divided in three major sections - supraglottis, glottis and subglottis.

Supraglottis possesses an extraordinary lymphatic drainage. Therefore, carcinomas in this area give metastases frequently in the cervical lymph nodes II, III, IV zones. Usually, problems with the therapy of supraglottic tumors arise mainly from cervical metastases rather than the initial tumor (15-17).

The frequency of patients cases in different stages of supraglottic carcinomas with clinically positive cervical lymph nodes when diagnosing them reaches $23-50 \% \mathbf{( 1 8 - 2 1 )}$. It is observed that primary supraglottic tumors are mostly non-keratinizing
K арциномът на ларинкса е най-честият малигнен тумор на главата и шията, като един от най-важните прогностични фактори е наличието на регионални метастази (29, 30, 7).

Шийните метастази при ларингеален карцином остават първата причина за неуспех в лечението и смърт на пациента (9). Така че третирането на шията трябва да бъде една от основните цели на всеки head and neck oncologist. Основният метод за лечение на шийните метастази остава шийната дисекция. Хирургията на шията спомага за отстраняване на всички уголемени лимфни възли при $\mathrm{N}+$ и дава точна хистологична информация при установени микрометастази при N0. Докато при клинично изявени мета поведението на хирурга е ясно, все още недобре изяснен е терапевтичният подход при N0 (10-14).

Ларинксьт се разделя на три отдела - супраглотис, глотис и субглотис.

Супраглотисът е с изключително добър лимфен дренаж, поради което карциномите в тази област често метастазират в шийните лимфни възли - II, III, IV зона. Обикновено проблемът с лечението на супраглотичните тумори идва по-скоро от шийните метастази, отколкото от първичния тумор (15-17).

Честотата на пациентите (със супраглотичен карцином различен стадий) с клинично позитивни шийни лимфни възли по време на поставяне на диагнозата достига 23 - 50\% (18-21). 
and poorly differentiated. Therefore, they possess more aggressive behavior (22).

Cell differentiation correlates with the possibility for cervical metastases (23-25). This is connected with survival rates (26). Therefore, differentiation of laryngeal carcinomas is linked to survival rates.

Glottis area is poorly lymph drained. Lymph drains towards supra- or subglottic areas which determines the appearance of metastases when a glottis tumor reaches more cranial or caudal zones. In cases of glottis carcinomas metastases are found in II, III, IV and VI zones (31). As far as the VI ${ }^{\text {th }}$ zone is concerned Waldfahrer et al. report that occult metastases are proven in that area in $18 \%$ of the cases (32).

Primary subglottic carcinoma cases are seldom diagnosed. They comprise $1-3 \%$ of malignant laryngeal tumors cases (33). Metastases in paratracheal lymph nodes (VI level) are more frequent in patients with primary subglottic carcinoma (34).

In $\mathrm{N} 0$ and $\mathrm{N} 1$ cases surgeons perform selective neck dissection, with preservation of $\mathrm{m}$. sternocleidomastoideus, $n$. accessorius and v. jugularis interna $(\mathbf{5}, \mathbf{8})$.

The basic principle for performing selective neck dissection lies mainly in the ways the metastatic process spreads in the related group of cervical lymph nodes (1). In laryngeal carcinoma cases in stages T3-T4 it is advisable to perform a selective neck dissection at levels II, III, IV - lateral neck dissection. What remains debatable is the need for dissection at level IV when metastases at level II-III are not present. Dissection at level IV is connected with higher morbidity levels (2). Two of the most important complications when dissecting at level IV are inflicting damage on ductus thoracicus and on n. phrenicus (6).

Lateral neck dissection represents a lymphadenectomy when treating oncologic diseases that affect the oropharynx, larynx, hypopharynx, and includes removing groups of lymph nodes at levels II, III and IV (selective neck dissection - SND II-IV). Patients with laryngeal carcinoma seldom have metastases in the submandibular triangle (level I) (35). Data from two studies support the usage of
Наблюдавано е, че първичните супраглотични тумори в по-голямата си част са некератинизиращи и слабо диференцирани карциноми. Следователно като цяло те имат по-агресивно поведение (22).

Клетъчната диференциация корелира с вероятността за шийни метастази (23-25). Това от своя страна има важно значение за преживяемостта (26). Следователно диференциацията на ларингеалните карциноми има отношение към преживяемостта.

Глотисът е с изключително беден лимфен дренаж. На практика лимфата се оттича към супраили субглотиса, което определя появата на мета при прорастване на глотичния тумор в краниална или каудална посока. При глотичния карцином метастази се наблюдават във II, III, IV и VI зона (31). По отношение на VI зона Waldfahrer et al. докладват за наличие на окултни метастази в тази зона при $18 \%$ от болните (32).

Първичният субглотичен карцином се среща рядко, като съставлява $1-3 \%$ от злокачествените ларингеални тумори (33). Метастази в паратрахеалните лимфни възли (VI ниво) са по-чести при пациенти с пьрвичен субглотичен карцином (34).

При N0 и N1 се извършва селективна шийна дисекция със запазване на МСКМ, н. акцесориус и вена югуларис интерна $(\mathbf{5}, \mathbf{8})$.

Принципът за извършване на селективна шийна дисекция се основава на пътищата на разпространение на метастатичния процес в съответната група шийни лимфни възли (1). При ларингеални карциноми в стадий Т3-T4 е препорьчително извършване на селективна шийна дисекция на II, III, IV ниво - латерална шийна дисекция. Остава спорен въпросьт от нуждата за извършване на дисекция на IV ниво при липса на метастази на II-III ниво, защото дисекцията на IV ниво е свързана с повишена заболеваемост (2). Двете най-важни усложнения при дисекция на IV ниво са увреждане на дуктус торацикус и на нервус френикус (6).

Латералната шийна дисекция представлява лимфаденектомия при лечението на ракови заболявания, засягащи орофаринкса, ларинкса, хипофаринкса, и включва отстраняване на групите на лимфните възли в нива II, III и IV (selective neck dissection - SND II-IV). Пациентите c карцином на ларинкса рядко имат метастази в 
SND II-IV as a treatment method for curing N0 laryngeal and hypopharyngeal carcinomas (36) and transglottic carcinomas (supraglottic tumors which pass the laryngeal ventricle and enter the glottis) (37). Anatomic margins of this lymphadenectomy are as follows: the clavicle from beneath, superiorly - the cranial base, lateral rim of sternohyoid muscle medially, laterally - the posterior rim of $\mathrm{m}$. sternocleidomastoideus and posteriorly - the skin sensory branches of the cervical plexus.

Apart from the glottic larynx, oncologic diseases of oropharynx, hypopharynx and larynx possess bilateral lymph drainage models. Thus the procedure of choice for patients with $\mathrm{N} 0$ and primary tumors in these places is bilateral SND II-IV when neck is treated surgically. In cancer cases, where the walls of the hypopharynx and oropharynx are affected, retropharyngeal lymph nodes may carry "the metastatic disease" as well. Therefore, removing of that key group lymph nodes must be considered. In laryngeal and hypopharyngeal carcinoma cases, spreading under the glottis, lymph nodes from level VI are usually included in the neck dissection (SND II-IV, VI), because they are at risk (37).

In laryngeal carcinoma cases occult metastases are proven in $37 \%$ of the patients with neck dissection. The metastatic process affects mainly levels II-IV. Seldom have authors proven metastases at level I (14\%) and level V(7\%) (3).

It is important to be noted that when comparing patients with lateral neck dissection (II-IV level) and modified radical neck dissection type III no significant difference in survivability rates for a mean period of follow-up of 42 months has been observed. This proves that lateral neck dissection is a method of choice for patients with supraglottic and transglottic laryngeal carcinoma (4).

Among 145 lateral neck dissections performed in 79 patients, metastases at level IV were observed in $2.5 \%$. After a 24-month follow-up, not a single case of relapse was observed (5). Some authors advise for a dissection at level IV only if there are clinically proven enlarged lymph nodes (2).

Paleri et al. after conducting analysis of the literature up to that moment reached a conclusion that metastases from a laryngeal carcinoma only in $0.4 \%$ of the субмандибуларния триъгълник (ниво I) (35). Данните от две проучвания подкрепят използването на SND II-IV за лечение на N0 ларингеални и хипофарингеални карциноми (36) и трансглотични карциноми (супраглотични тумори, които преминават ларингеалния вентрикул и нахлуват в глотиса) (37). Анатомичните граници на тази лимфаденектомия са, както следва: ключицата отдолу, черепната основа отгоре, латералният ръб на стернохиоидния мускул медиално, задния ръб на МСКМ латерално и кожните сензорни клонове на шийния сплит отзад.

С изключение на глотичния ларинкс, раковите заболявания на орофаринкса, хипофаринкса и ларинкса имат двустранни модели на лимфен дренаж. По този начин процедурата за избор на пациенти с N0 и пьрвични тумори в тези места е двустранна SND II-IV, когато шията се лекува хирургично. При ракови заболявания, засягащи стените на хипофаринкса и орофаринкса, ретрофарингеалните възли могат да носят метастатична болест. Следователно при това обстоятелство трябва да се обмисли премахването на тази възлова група. При ларингеални и хипофарингеални карциноми, простиращи се под глотиса, лимфните възли от ниво VI обикновено се включват в дисекцията на шията (SND II - IV, VI), защото са изложени на риск (37).

При ларингеалния карцином окултни метастази са доказани в $37 \%$ от болните с шийна дисекция, като метастатичният процес ангажира основно II-IV ниво. Много рядко са установени мета на ниво I (14\%) и ниво V (7\%) (3).

Важно е също да се отбележи, че при сравняване на пациенти с латерална шийна дисекция (II-IVниво) и модифицирана радикална шийна дисекция тип III не е установена разлика по отношение преживяемостта за среден период на проследяване от 42 месеца. Това доказва, че латералната шийна дисекция е метод на избор при болни със супраглотичен и трансглотичен ларингеален карцином (4).

При 145 латерални шийни дисекции, проведени при 79 болни, мета в IV ниво са установени при 2,5\%. При 24-месечно проследяване при нито един болен не е наблюдаван рецидив (5). Някои автори препоръчват дисекция на ниво IV само при наличие на клинично уголемени лимфни възли (2).

Paleri et al. след проведен анализ на литературата до момента стигнали до извода, че при мета 
cases is level IIB affected providing that patient is N0 radiologically and clinically (27).

According to some authors by utilizing routine methods of clinical investigation it is not possible to prove micrometastases below $2 \mathrm{~mm}$, even below $5 \mathrm{~mm} \mathrm{(28).} \mathrm{Therefore,} \mathrm{it} \mathrm{is} \mathrm{likely} \mathrm{that} \mathrm{microme-}$ tastases in regional lymph nodes are frequently underestimated.

\section{Surgical anatomy of zones II, III and IV}

\section{Zone II - Upper group jugular lymph nodes}

Zone II represents the start of the jugular chain. Here, scientists include the lymph nodes around the internal jugular vein in her upper third and around n. accessorius in its most superior part. Margins of zone II are as follows: superiorly - the posterior belly of $\mathrm{m}$. digastricus with the mastoid process, inferiorly - the hyoid bone (or the bifurcation of the carotid artery as a surgical marker) anteriorly - the posterior part of the submandibular gland, posteriorly - the posterior rim of $\mathrm{m}$. sternocleidomastoideus, laterally - the medial surface of $\mathrm{m}$. sternocleidomastoideus, medially - the internal carotid artery and mm. scalene. Lymph nodes from zone II are connected with efferent lymph vessels from the face, parotid gland, zone I and the retropharyngeal lymph nodes. In zone II drained directly are the nasal cavity, pharynx, larynx, external auditory canal, middle ear, sublingual and submandibular glands. Most frequently here are found metastases from tumors in the nasal cavity, oral cavity, nasopharynx, oropharynx, hypopharynx, larynx and major salivary glands. Zone II is most frequently involved zone in cervical metastases $(37,38,39,40,41)$.

\section{Zone III - Middle group jugular lymph nodes}

Zone III includes the middle group of cervical lymph nodes which are situated around the middle third of the internal jugular vein. Margins of the zone are as follows: superiorly - the hyoid bone, inferiorly - the caudal end of the cricoid cartilage (or m. omohyoideus as a surgical marker), anteriorly - the frontal rim of $\mathrm{m}$. sternocleidomastoideus, posteriorly - the posterior rim of $\mathrm{m}$. sternocleidomastoideus, laterally - the medial surface of $\mathrm{m}$. sternocleidomastoideus, medially - the internal carotid artery. от ларингеален карцином само в 0,4\% е ангажирано ниво IIB при радиологично и клинично N0 (27).

Според някои автори чрез рутинните методи на изследване не е възможно да бъдат установени микрометастази под 2 мм, дори под 5 мм (28). Така че е твърде вероятно микрометастазите в регионалните лимфни възли често да са подценявани.

\section{Хирургична анатомия на II, III и IV зона}

\section{1. Зона II - Горна група югуларни лимфни възли}

II зона представлява началото на югуларната верига.Тук се включват лимфните възли около вътрешната югуларна вена в горната ѝ трета и около нервус акцесориус в най-горната му част. Границите на II зона са следните: нагоре - задното коремче на м. дигастрикус с пр. мастоидеус, надолу - хиоидната кост (или бифуркацията на каротидната артерия като хирургичен пойнтер), напред - задната част на субмандибуларната жлеза, назад - задният ръб на м. стерноклейдонастоидеус, латерално - медиалната повърхност на МСКМ, медиално - вътрешната каротидна артерия и мускули скалени. До лимфните възли от II зона достигат еферентни лимфни съдове от лицето, околоушната слюнчена жлеза, I зона и ретрофарингеалните лимфни възли. Във втора зона директно се дренират носната кухина, фаринксът, ларинксът, външния слухов проход, средното ухо, сублингвалната и субмандибуларната жлеза. Най-често тук се откриват метастази от тумори на носната кухина, устната кухина, назофаринкса, орофаринкса, хипофаринкса, ларинкса и големите слюнчени жлези. Втора зона е най-често въвлечената зона при шийните метастази $(37,38,39,40,41)$.

\section{2. Зона III - Средна група югуларни лимфни възли}

Трета зона включва средната група шийни лимфни възли, разположени около средната трета на вътрешната югуларна вена. Границите на трета зона са следните: отгоре - хиоидната кост, отдолу - каудалният край на крикоидния хрущял (или м. омохиоидеус като хирургичен маркер), отпред - предният ръб на МСКМ, отзад - задният ръб на МСКМ, латерално - медиалната повърхност на МСКМ, медиално - вътрешната сънна артерия. До лимфните възли в трета зона достигат ефе- 
Lymph vessels in this zone are connected with lymph vessels from zone II and V, partially connection is observed with retropharyngeal and pretracheal lymph nodes. A direct drain is typical for the lingual base, tonsils, larynx, hypopharynx and the thyroid gland. Here, most frequently tumors from the nasopharynx, oropharynx, hypopharynx and larynx can metastasize $(\mathbf{4 2}, \mathbf{4 3}, \mathbf{4 4})$.

\section{Zone IV - Lower group of jugular lymph nodes.}

These are the lymph nodes that are situated around the lower third of the internal jugular vein. Margins of the zones are as follows: cranially - the inferior rim of the cricoid cartilage, caudally - the clavicle, anteromedially - the lateral rim of $\mathrm{m}$. sternohyoideus, posterolaterally - the posterior rim of $\mathrm{m}$. sternocleidomastoideus. Here, metastases from the hypopharynx, the larynx and the cervical part of the esophagus may be found.

In our clinic, we have implemented the following technique for lateral neck dissection: the position of the patient on the operating table is supine. We put a roll beneath the scapulae for maximal extension of the head. We maximally rotate the head to the contralateral side. We apply to the skin of the whole neck region (from the mandible to beneath the clavicles, posteriorly to $\mathrm{m}$. trapezius) two times Braunol solution. The incision on the skin starts at proc. mastoideus, extends following the posterior rim of $\mathrm{m}$. sternocleidomastoideus and meets the incision for the tracheotomy. We cut skin, subcutaneous and platysma layers. We elevate subplatisma flaps. If we are going to perform a laryngectomy as well, we elevate U-type flap. This flap we elevate a bit above the level of the hyoid bone, usually we even reach the inferior parts of the submandibular glands. After we have elevated the U-type flap, we fix it with two sutures to the chin. If the elevation is performed in a correct manner, above $\mathrm{m}$. sternocleidomastoideus (in its superior portion) we must see $n$. auricularis magnus and $\mathrm{v}$. jugularis externa. A ligation of the vein and an incision on it are performed, the nerve should be preserved. $\mathrm{N}$. auricularis magnus is then dissected and hold cranially. After we have elevated the cervical flap, we should visualize the superficial cervical fascia which covers the tissues. With surgical scissors we cut the fascia at the posterior rim of $\mathrm{m}$. sternocleidomastoideus to the mastoid process and the clavicle and elevate it from the muscle medially. By continuing the dissection, we reach the medial- рентни лимфни съдове от зона II и зона V, отчасти от ретрофарингеални и претрахеални лимфни възли. Директно се дренират базата на езика, тонзилите, ларинксьт, хипофаринксьт и щитовидната жлеза. Тук най-често метастазират туморите на назофаринкса, орофаринкса, хипофаринкса и ларинкса $(42,43,44)$.

\section{3. Зона IV - Долна група югуларни лимфни възли.}

Това са лимфните възли, разположени около долната трета на вътрешната югуларна вена. Границите на IV зона са следните: краниално долният ръб на крикоидния хрущял на ларинкca, каудално - клавикулата, антеро-медиално - латералния ръб на мускулус стернохиоидеус, постеро-латерално - задният ръб на МСКМ. Тук се срещат метастази от хипофаринкса, ларинкса, шийната част на хранопровода.

В нашата клиника прилагаме следната техника на латерална шийна дисекция. Позицията на болния на операционната маса е по гръб. Поставяме ролка под скапулите за максимална екстензия на главата. Ротираме главата максимално на срещуположната страна. Двукратно почистваме кожата с браунол на цялата шия от мандибулата до под ключиците, назад до м. трапециус. Разрезът на кожата започва от процесус мастоидеус, продължава по задния ръб на МСКМ и се свързва с разреза от трахеотомията. Срязваме кожата, подкожие и платизма. Повдигаме субплатизмални ламба. Ако ще извършваме и ларингектомия, повдигаме U-образно ламбо. Това ламбо повдигаме малко над нивото на подезичната кост, като обикновено достигаме и до долните полюси на субмандибуларните жлези. След като сме повдигнали U-образното ламбо, го фиксираме с два шева към брадичката. При правилно повдигане на ламбото, върху МСКМ (в горната му половина) трябва да виждаме нервус аурикуларис магнус и външната югуларна вена. Лигираме вената и я прерязваме, нерва трябва да опитаме да го запазим. Нервус аурикуларис магнус се отпрепарира от подлежащите тъкани и го екартираме краниално. След като сме повдигнали шийното ламбо, ще визуализираме повърхностната шийна фасция, която покрива тьканите. С ножица прерязваме повърхностната фасция по задния ръб на МСКМ по цялата дължина от мастоида до клавикулата и отпрепарираме фасцията от 
posterior surface of $\mathrm{m}$. sternocleidomastoideus. In the inferior half of the operating field we reach $\mathrm{m}$. omohyoideus which is dissected and incised. Beneath it, we find the internal jugular vein (IJV), common carotid artery (CCA) and the vagal nerve. We then move to the superior half of the operating field and perform a blunt dissection to find $\mathrm{n}$. accessorius medially to $\mathrm{m}$. sternocleidomastoideus (it enters the muscle approximately between its superior and medial third). N. accessorius extends oblique in the fat tissue between $\mathrm{m}$. sternocleidomastoideus and IJV. With a dissector we release the fat tissue above the nerve and cut it. But we must profoundly dissect the whole nerve from $\mathrm{m}$. sternocleidomastoideus to IJV. In most patients the nerve passes above the IJV. The next step is a dissection in zone IIB. Therefore, we perform a sharp dissection with surgical scissors by starting from the angle between $\mathrm{m}$. sternocleidomastoideus and $\mathrm{m}$. digastricus. Here, in most cases, the occipital artery is damaged but the bleeding is easily put under control with bipolar coagulation forceps. We gradually separate the fat tissue caudally while reaching $\mathrm{m}$. splenius capitis and $\mathrm{m}$. levator scapulae in depth. When the level of $n$. accessorius is reached, we use the method of O. Suarez to lift the nerve and we pass the dissected beneath the nerve caudally. We continue with the separation of the dissected tissues caudally and in depth we visualize the cervical plexus. We dissect the tissues away from the plexus - usually we cut through the frontal sensory branches of the plexus, while the posterior ones must be preserved. Up to this moment, we have performed a dissection of zone IIB and partially of zones IIA and III. We go back to the inferior half of the operating field where earlier we visualized IJV, CCA and the vagal nerve. We dissect the IJV and CCA in their lower portions by releasing them from the fascia. After that, bluntly, with a dissector, we penetrate in depth, laterally from IJV and caudally from $\mathrm{m}$. omohyoideus. We must visualize prevertebral musculature (mm. scalene) and, in particular, a. et v. transversus coli. Bluntly, gradually, we remove the fat tissue (situated between IJV and m. sternocleidomastoideus) from the prevertebral musculature while advancing cranially. We must not penetrate through the deep cervical fascia, she is the margin of dissection in depth. So far, we have also dissected zone IV - we must clearly observe the transversal cervical vessels in the lower part of the surgical field. Next, we separate the dissected мускула медиално. Чрез постепенна дисекция достигаме до медиално-задната повърхност на МСКМ. В долната половина на полето установяваме м. омохиоидеус, който го дисецираме и прерязваме. Под м. омохиоидеус намираме вена югуларис интерна (ВЮИ), а. каротис комунис (АКК) и нервус вагус (НВ). Преминаваме в горната част на оперативното поле, като чрез тъпа дисекция намираме н. акцесориус медиално от МСКМ (влиза в мускула приблизително между горната и средната му трета). Нервус акцесориус върви косо в мастната тъкан между МСКМ и ВЮИ. С дисектор освобождаваме мастната тъкан над нерва и я прерязваме. Трябва добре да отделим нерва по цялата му дължина между МСКМ и ВЮИ. При повечето болни акцесорният нерв преминава над ВЮИ. Следващата стьпка е дисекция на зона II В. За целта прилагаме остра дисекция с ножица като започваме от ъгъла между МСКМ и м. дигастрикус. Тук почти винаги при дисекцията се наранява окципиталната артерия, но кървенето лесно се овладява с биполярна пинсета. Отделяме постепенно мастната тъкан каудално, като в дълбочина трябва да достигнем до м. сплениус капитис и м. леватор скапуле. Когато препаратьт достигне до нивото на акцесорния нерв, използваме прийома на О. Suarez, като повдигаме н. акцесориус и прекарваме препарата под нерва в каудална посока. Продължаваме с отделяне на препарата каудално, като в дълбочина ще визуализираме шийния плексус. Дисецираме препарата от плексус цервикалис, като обикновено прерязваме предните сензорни клончета на плексуса, но задните дълбоки задължително трябва да бъдат запазени. До този момент сме направили дисекция на зона IIB и частично на зона II A и III. Връщаме се в долната половина на полето, където по-рано бяхме визуализирали ВЮИ, АКК и НВ. Дисецираме ВЮИ и АКК в долната им част, като ги освобождаваме от фасцията. След това тъпо с дисектор проникваме в дълбочина, латерално от ВЮИ и каудално от м. омохиоидеус. Трябва да визуализираме превертебралната мускулатура (мм. скалени) и в частност а. и вена транзверза коли. Тъпо постепенно отделяме мастната тькан (разположена между ВЮИ и МСКМ) от превертебралната мускултура, като се движим в краниална посока. Не трябва да навлизаме през дълбоката шийна фасция, тя е границата на дисекцията в дълбочина. Така вече сме дисе- 
tissues away, medially to the fascia of $\mathrm{m}$. sternohyoideus. We grip the tissues dissected up to that moment together - this includes the tissue from zone IV and the tissue from zone IIB, III. The assistant of the operator pulls it superiorly and medially. Gradually, we dissect it bluntly from IJV, CAA, the carotid bifurcation and $n$. hypoglossus, up to m. digastricus, where we cut it through. Lastly, we usually have to ligate $\mathrm{v}$. facialis and the superior thyroid vein. We perform a profound hemostasis. We irrigate the operating field with hydrogen peroxide solution, physiological solution and Braunol solution. We place an aspirating drainage. The incision is closed at two stages - first we connect the platysma and then - the skin layer. We use standard single interrupted sutures. The drainage is removed at the third postoperative day while the sutures are removed after seven days. цирали и IV зона, като добре трябва да виждаме транзверзалните шийни съдове в долната част на полето. Следва отделяне на препарата медиално от фасцията на м. стернохиоидеус. Захващаме целия препарат до момента заедно - това включва дисецирания препарат от IV зона и препарата от зона IIB, III. Асистентът го тегли нагоре и медиално. Постепенно го отпрепарираме тъпо от ВЮИ, АКК, бифуркацията на каротиса и нервус хипоглосус до м. дигастрикус, където го прерязваме. При последната стьпка обикновено трябва да лигираме вена фациалис и горната тироидна вена. Извършваме щатетална хемостаза. Промиваме оперативното поле с кислородна вода, физиологичен разтвор и браунол. Поставяме аспирационен дрен. Разреза затваряме на два етажа - първо съединяваме платизмата и след това кожата. Използваме стандартен единичен прекъснат шев. Дренажа премахваме на третия постоперативен ден, а шевовете на седмия ден.

\section{References:}

1. Robbins KT, Shaha AR, Medina JE, et al. Committee for Neck Dissection Classification, American Head and Neck Society, author. Consensus statement on the classification and terminology of neck dissection. Arch Otolaryngol Head Neck Surg. 2008; 134: 536-538.

2. Khafif A, Fliss DM, Gil Z, et al. Routine inclusion of level IV in neck dissection for squamous cell carcinoma of the larynx: is it justified? Head Neck. 2004; 26: 309-312.

3. Shah JP. Patterns of cervical lymph node metastasis from squamous carcinomas of the upper aerodigestive tract. Am J Surg. 1990; 160: 405-409.

4. Brazilian Head and Neck Cancer Study Group, author. End results of a prospective trial on elective lateral neck dissection vs type III modified radical neck dissection in the management of supraglottic and transglottic carcinomas. Head Neck. 1999; 21: 694-702.

5. Leyn X, Quer M, Orъs C, et al. Selective dissection of levels II-III with intraoperative control of the upper and middle jugular nodes: a therapeutic option for the N0 neck. Head Neck. 2001; 23: 441-446.

6. Lim YC, Choi EC, Lee JS, et al. Is dissection of level IV absolutely necessary in elective lateral neck dissection for clinically N0 laryngeal carcinoma? Oral Oncol. 2006; 42: 102-107.

7. Tomik J, Skladzien J, Modrzejewski M. Evaluaton of cer- vical lymph node metastasis of 1400 patients with cancer of the larynx. Auris Nasus Larynx 2001; 28: 233-240

8. Spriano G, Piantanida R, Pellinli R, Muscatello L. Elective treatment of the neck in squamous cell carcinoma of the larynx: clinical experience. Head Neck 2003; 25: 97-102.

9. Shah JP, Patel KJ. Head and Neck Surgery and Oncology. 3rd Ed., Edinburgh: Mosby 2003

10. Spector JG, Sessions DG, Haughey BH, Chao KS, Simpson J, El Mofty S, et al. Delayed regional metastases, distant metastases, and second primary malignancies in squamous cell carcinomas of the larynx and hypopharynx. Laryngoscope 2001; 111: 1079-87.

11. Ferlito A, Bradley PJ, Rinaldo A. What is the treatment of choice for Tl squamous cell carcinoma of the larynx? J Laryngol Otol 2004; 118: $747-9$

12. Ferlito A, Rinaldo A, Silver CE, Gourin CG, Shah JP, Clayman GL, et al. Elective and therapeutic selective neck dissection. Oral Oncol 2006; 42: $14-25$.

13. Ferlito A, Rinaldo A, Silver CE, Shah JP, Suarez C, Medina JE, et al. Neck dissection: then and now. Auris Nasus Larynx 2006; 33 : 365-74.

14. Wei WI, Ferlito A, Rinaldo A, Gourin CG, Lowry J, Ho WK, et al. Management of the N0 neck - reference or preference. Oral Oncol 2006; 42: $115-22$

15. Lindberg R. Distribution of cervical lymph node metastases from squamous cell carcinoma of the upper respiratory and digestive tracts. Cancer 1972; 29: 1446-9.

16. Crissman JD. Laryngeal keratosis and subsequent carcinoma. Head Neck Surg 1979; 1: 386-91

17. Levendag P, Vikram B. The problem of neck relapse in early stage supraglottic cancer - results of different treatment modalities for the clinically negative neck. Int J Radiat Oncol Biol Phys 1987; 13: 1621-4.

18. Ogura JH, Sessions DG, Spector GJ. Conservation surgery for epidermoid carcinoma of the supraglottic larynx. Laryngoscope 1975; 85: 180815

19. Kirchner JA, Owen JR. Five hundred cancers of the larynx and pyriform sinus. Results of treatment by radiation and surgery. Laryngoscope 1977; 87: 1288-303

20. Hansen HS. Supraglottic carcinoma of the aryepiglottic fold. Laryngoscope 1975; 85: 1667-81.

21. Shah JP, Tollefsen HR. Epidermoid carcinoma of the supraglottic larynx. Role of neck dissection in initial surgical treatment. Am J Surg 1974; 128: 494-9. 
22. McGavran MH, Bauer WC, Ogura JH. The incidence of cervical lymph node metastases from epidermoid carcinoma of the larynx and their relationship to certain characteristics of the primary tumour. A study based on the clinical and pathological findings for 96 patients treated by primary en bloc laryngectomy and radical neck dissection. Cancer 1961; 14: 55-66.

23. Lauerma S. Treatment of laryngeal cancer. A study of 638 cases. Acta Otolaryngol Ital 1967; (Suppl 225): 1.

24. Kashima HK. The characteristics of laryngeal cancer correlating with cervical lymph node metastasis. Can J Otolaryngol 1975; 4: 893-902

25. Reid AP, Robin PE, Powell J, McConkey CC, Rockley T. Staging carcinoma: its value in cancer of the larynx. J Laryngol Otol 1991; 105: 456-8.

26. Spiro RH, Alfonso AE, Farr HW, Strong EW. Cervical node metastasis from epidermoid carcinoma of the oral cavity and oropharynx. A critical assessment of current staging. Am J Surg 1974; 128: 562-7.

27. V. Paleri, S. Kumar Subramaniam, N. Oozeer, et al. Dissection of the submuscular recess (sublevel IIb) in squamous cell cancer of the upper aerodigestive tract: prospective study and systematic review of the literature Head Neck, 30 (2) (2008), pp. 194-200.

28. V. Burcia, V. Costes, J.L. Faillie, et al. Neck restaging with sentinel node biopsy in T1-T2N0 oral and oropharyngeal cancer: Why and how? Otolaryngol Head Neck Surg, 142 (4) (2010), pp. 592-597.

29. Rahman SH, Alauddin M, Ahmed K, Shaheen MM. Significance of Association between Sociodemographic features and the site of Laryngeal carcinoma. J Dhaka Med Coll. 2003; 12(1): 12-21.

30. Moe K, Wolf GT, Fisher SG, Hong WK. Regional metastases in patients with advanced laryngeal carcinoma. Arch Otolaryngol Head Neck Surgery. 1996; 122: 644-648.

31. Armstrong WB, Vokes DE, Verma SP. Malignant Tumor of the Lar ynx. In: Flint PW, Haughey BH, Lund VJ, Niparko JK, Robbins KT, Thomas JR, et al (editors). Cummings Otolaryngology Head and Neck Surgery, 6th ed. Vol 2. Philadelphia (PA): Mosby, c2010. P16131614.

32. Waldfahrer F, Hauptmann B, Iro H. [Lymph node metastasis of glottic laryngeal carcinoma]. Laryngorhinootologie. 2005 Feb; 84(2): 96-100. Epub 2005/02/16. DOI: 10.1055/s-2004-826075; PMID: 15712044।

33. Santoro R, Turelli M, Polli G. Primary carcinoma of the subglottic lar ynx. Eur A rch Otorhinolaryngol. 2000 Dec; 257(10): 548-51. Epub 2001/02/24. PMID: 11195034

34. Coskun HH, Medina JE, Robbins KT, Silver CE, Strojan P, Teymoortash A, et al. Current philosophy in the surgical management of neck metastases for head and neck squamous cell carcinoma. Head Neck. 2015 Jun; 37(6): 915-26. Epub 2014/03/14. DOI: 10.1002/hed.23689; PMID: 24623715 PMCID: PMC4991629

35. Dos Santos CR, Magrin J, Ferlito A, Filho JG, Johnson LFP, Kowalski LP. Involvement of level I neck lymph nodes in advanced squamous carcinoma of the larynx. Ann Otol Rhinol Laryngol 2001; 110: 982-4.

36. Buckley JG, MacLennan K. Cervical node metastases in laryngeal and hypopharyngeal cancer: a prospective analysis of prevalence and distribution. Head Neck 2000; 22: 380-5.

37. Ishikawa M, Anzai Y. MR imaging of lymph nodes in the head and neck. Neuroimaging Clin. N. Am. 2004 Nov; 14(4): 679-94.

38. Ho FC, Tham IW, Earnest A, Lee KM, Lu JJ. Patterns of regional lymph node metastasis of nasopharyngeal carcinoma: a meta-analysis of clinical evidence. BMC Cancer. 2012 Mar 21; $12: 98$.

39. Candela FC, Kothari K, Shah JP. Patterns of cervical node metastases from squamous carcinoma of the oropharynx and hypopharynx. Head Neck. 1990 May-Jun; 12(3): 197-203.

40. Candela FC, Shah J, Jaques DP, Shah JP. Patterns of cervical node metastases from squamous carcinoma of the larynx. Arch. Otolaryngol. Head Neck Surg. 1990 Apr; 116(4): 432-5.

41. Hicks WL, Kollmorgen DR, Kuriakose MA, Orner J, Bakamjian VY, Winston J, Loree TR. Patterns of nodal metastasis and surgical management of the neck in supraglottic laryngeal carcinoma. Otolaryngol Head Neck Surg. 1999 Jul; 121(1): 57-61.

42. Shah JP, Candela FC, Poddar AK. The patterns of cervical lymph node metastases from squamous carcinoma of the oral cavity. Cancer. 1990 Jul 01; 66(1): 109-13.

43. Montero PH, Patel SG. Cancer of the oral cavity. Surg. Oncol. Clin. N. Am. 2015 Jul; 24(3): 491-508.

44. Farmer RW, McCall L, Civantos FJ, Myers JN, Yarbrough WG, Murphy B, O’Leary M, Zitsch R, Siegel BA. Lymphatic drainage patterns in oral squamous cell carcinoma: findings of the ACOSOG Z0360 (Alliance) study. Otolaryngol Head Neck Surg. 2015 Apr; $152(4)$ ): $673-7$. 